\title{
Sustainability accounting and corporate social responsibility in Turkey and in its region
}

\author{
Nalan Akdogan ${ }^{\mathrm{a}}$, Seval Kardes Selimoglu ${ }^{1}$, Medine Turkcan ${ }^{\mathrm{a}}$ \\ a Baskent University, Bă̆lıca Campus, Ankara, Turkey
}

\begin{abstract}
Research question: As a newly developing area, this paper aims investigate recent developments and applications of social responsibility practices in Turkey and in the neighboring regions in a comparative way. Motivation: The sustainability reporting is relatively a new subject in Turkey both in practice and in academic circles. The introduction of Corporate Social Responsibility as a concept in Turkey does not have a long history. The last five years witnessed a significant change in terms of corporate social responsibility (CSR) applications. Increasing number of companies started to implement sustainability accounting and corporate social responsibility practices. Companies began to adopt corporate social responsibility by considering it as a tool for medium- and long-term success. As a reflection of growing interest in sustainability and CSR, the number of NGO's and consultancy firms operating in this field has also increased recently. In 2014, Sustainability Index was created within the Istanbul Stock Exchange (ISE). Idea: The understanding of the social responsibility applications and priority areas vary between different countries depending on their economic, social and political dynamics. In order to see the intra-regional variations, in this paper, we compare corporate social responsibility and sustainability applications in Turkey and in the neighboring regions by selecting Russia and Greece in the same region. Data: For the analysis, we collect recent sustainability reports of Turkish companies from GRI database and make a content analysis to evaluate practical applications of CSR and sustainability in Turkey. Then, we discuss corporate social responsibility applications in Russia and Greece. In the first part of our paper we examine corporate social responsibility and sustainability applications in Turkey by making an analysis of sustainability reports and CSR activities in Turkey. In the following part we discuss corporate social responsibility applications in the neighboring regions and make a comparison with Turkey. To this end, sustainability reports of Russian Federation and Greek companies in GRI database are analyzed for CSR activities. In the final part of our paper, we make a comparative analysis of CSR applications in Turkey and in the
\end{abstract}

1 Corresponding author: Department of Accounting, Business Administration Faculty, Anadolu University, Yunus Emre Campus, Eskisehir/ Turkey, 26470, Email: sselimoglu@anadolu.edu.tr 
neighboring regions. Findings: The final analysis of CSR in Turkey and neighboring countries supports the idea that understanding of CSR varies in different countries depending on their social structure and economic development level.

Keywords: Corporate social responsibility, sustainability accounting, sustainability index

\section{JEL codes: M14, M41}

\section{Introduction}

"Social responsibility can only become reality if more managers become moral instead of amoral or immoral." (Caroll, 1991)

The sustainability idea firstly emerged as an economic concept and sustainability and sustainable economic development are used interchangeably, leaving social and environmental dimensions of sustainability in an inferior position. Starting from mid 1970's, people started to talk about the dangers of massive economic development for the environment and for the whole society in general. Currently the idea of sustainability evolved into a more sophisticated idea of considering sustainability as the rights of future generations and leaving them a "clean" environment and living conditions while mankind continues its economic development.

The awareness of sustainable development also increased as a result of efforts of various international organizations and NGO's. United Nations has played a pioneering role in sustainable development issues. Sustainable development first came to attention of the world in a global scale with 1972 Stockholm Conference of UN in which attending countries discussed for the first-time negative impacts of economic development on the environment. The 1982 UN Summit in Rio de Janeiro was a turning point where UN Convention on Biodiversity, Convention to Combat Desertification and Framework Convention on Climate Change were opened for signature of attending states.

As part of ongoing efforts of United Nations to promote sustainability, UN General Assembly defined 17 sustainable development goals in 2030 Agenda of United Nations as a blueprint to achieve a better and more sustainable future for the world. The goals address the global challenges including poverty, inequality, climate, environmental degradation, prosperity, peace and justice. OECD is the other international organization working actively on sustainable development by monitoring the sustainability through its sustainable development indicators.

Advances in management systems, reporting standards, use of technology and growing attention on environmental, social and economic sustainability accelerated 
the importance of sustainability issues among companies. According to Chiu (2010), CSR reporting has moved from dominantly environmental reporting to more general sustainability reports encompassing various areas of social interest such as community and social impact, and human capital reporting. Three key developments witnessed over the last five years include the development of autonomous or standalone CSR reports, the acceptance and adoption of standardized reporting guidelines, in particular, those developed by the Global Reporting Initiative ("GRI"), and the growth of CSR ratings and thirdly the development of the assurance industry for CSR reports.

International organizations and initiatives have also played a guiding role for companies in forming sustainability reports which can be defined as written public declarations of companies on their social, environmental and corporate management activities. Currently, reporting of CSR is realized according to four different reporting frameworks: 1- G4 reporting framework of Global Reporting Initiative (GRI) 2- Communication on Progress (COP) reporting of UN Global Compact 3Integrated Reporting (IR) framework of International Integrated Reporting Council (IIRC) 4- Carbon Disclosure Project (CDP) reporting of Carbon Disclosure Project. It is observed that most companies prefer to use the G4 reporting framework for CSR reporting.

As a reflection of growing awareness on sustainable development, countries started to develop sustainability indexes according to social, environmental and economic performances of companies. In the late 1990's Dow Jones sustainability index was launched as a first global indicator on sustainability.

Contemporary understanding of sustainability is based on three main pillars: economic, social and environmental. The concept of corporate sustainability is seen as an indispensable part in achieving these three pillars of sustainability in that the terms of sustainability and corporate sustainability are used synonymously. Corporate sustainability offers various tools to transform conceptual idea of sustainability into more practical and concrete results and actions. The concepts of sustainable economic development, corporate social responsibility (CSR), corporate accountability and stakeholder theory has developed under the general heading of corporate sustainability among which corporate social responsibility having the utmost importance (Pekdemir, 2013). Studies of Caroll made important contributions to the formation of contemporary understanding of the corporate social responsibility. Carroll (1991) specified economics, law, ethics and philanthropic domains as the main elements of corporate responsibility that companies should realize in their CSR performance to achieve community demands and acceptance. These so called four responsibilities then formed CSR pyramid of Carroll. In general definition, corporate social responsibility refers to ethical, social and environmental responsibilities of companies while undertaking their everyday business activities in which broad range of activity areas are covered such as environmental protection, healthcare, education, social justice and equality, social rights and workforce equality. 
Emergence of sustainability reporting and studies on sustainability in Turkey coincides with global developments on sustainability. Turkey signed international treaties of UN on environment and ecological protection in 1990's. In 2004, National Sustainable Development Commission was formed to formalize national strategies and plans on sustainable development. In 2014, Sustainability Index was created within the Istanbul Stock Exchange (ISE). Government and companies in Turkey consider sustainable development as a way to increase international competitiveness of Turkish companies in global arena. Government promotes sustainability reporting and sustainable development issues as part of its national development plan.

As stated above the sustainability reporting is relatively a new subject in Turkey both in practice and in academic circles. Academic studies on the CSR and sustainability studies in Turkey started to gain momentum after 2010 focusing on mainly two broad categories of content analysis of CSR reports in selected sectors in Turkey and the studies attempting to measure the impact of CSR applications on the company's performances. This paper aims to contribute academic literature on Turkey by making a recent and thorough review of CSR reports of Turkish companies in terms of their contents and making a comparison with its neighboring countries in order to see the intra-regional variations in CSR reporting that is lacking in the current literature.

In this paper, we will follow a comparative analysis of corporate social responsibility and sustainability applications in Turkey and in the neighboring regions. The following of our paper is structured in four parts. In the first part, current literature and academic studies on corporate social responsibility are presented. The first part of the paper also covers historical development of sustainability and CSR reporting in Turkey in order to give a complete picture of CSR as a newly developing area in Turkey. In the second part, we examine sustainability and corporate social responsibility applications in Turkey. For our analysis, we collect recent sustainability reports of Turkish companies from GRI database and make a content analysis to evaluate practical applications of CSR and sustainability in Turkey. Then, we discuss corporate social responsibility applications in the neighboring region. For this aim we selected Russia and Greece as representatives for analyzing sustainability and CSR applications in the region since both countries have similar levels of development in the region. In the final part of our paper, we make a comparative analysis of CSR applications in Turkey and in the neighboring regions.

\section{Literature review}

The ideas of ethical, environmental, social responsibilities of companies and sustainable development originate from developed countries of the west especially from North America. First academic writings and research on CSR and sustainability mainly focused on relationship between the social responsibilities and financial performance of the companies. First definitions of CSR can be found in Bowen's (1953) and Barnard's studies in 1950's and 60's. In Barnard's extensive work called 
"functions of the executives" (1968), he defines CSR as "economic, legal, moral, social and physical aspects of business environment". Carroll (1979) made a more elevated definition of CSR and developed a four-level understanding of CSR as economic, legal, ethical and discretionary (philanthropic) responsibilities of a company. Caroll (1979) defined CSR as:

"The social responsibility of business encompasses the economic, legal, ethical and discretionary expectations that society has of organizations at a given point in time."

Apart from four-dimensional model, he also developed "the Pyramid of CSR" in 1991. According to this hierarchical model, he lists responsibilities of a company as economic performance at the bottom, followed by legal, ethical issues and continues with philanthropic responsibilities at the top in a hierarchy. Later, Schwartz and Caroll (2003) modified his early four-level definition of CSR and came up with Three-Dimensional Model of CSR as economic, legal and ethical responsibilities.

European scholars had gradually entered the discussion of CSR and gained momentum across all European countries starting from mid-2000's. Yet, as Maon et al. (2017) stated in their recent analysis, comparative, pan-European studies of actual CSR practices developed by corporate actors are scarce. Most practice-focused CSR studies provide a single-country analysis. In their comprehensive study, Maon et al. (2017) conducted a comparative study including 499 CSR initiatives implemented by 178 companies in five distinct, institutionally consistent European clusters and found that CSR actions are characterized by strong differences among companies that distinguish regional clusters. Albareda et al. (2007) and Jackson and Apostolakou (2010) also conducted comparative studies in the European level analyzing he factors shaping CSR practices considering the role of governments and other institutional actors. While most studies in the field of CSR mainly focusing on West European countries, Albu et al. (2016) investigated CSR practices in Central and East European region focusing on similarities and differences among selected Central and East European countries. The other studies focused on different aspects of CSR like quality of CSR reporting (Beelde \& Tuybens, 2015), CSR and bank risk profile (Gambetta et al., 2017). Jain et al. (2011) analyzed the link between psychosocial risk management and SCR practices through questionnaire and interviews across Europe.

When we look at the academic literature on CSR and sustainability studies in Turkey, we see proliferation of the academic studies after 2010 which coincides with the leaping of the number of Turkish companies publishing CSR reports. Two mainstream academic literatures in Turkey on CSR and sustainability revolve around content analysis of CSR reports in selected sectors in Turkey, including a comparative analysis with other countries and econometric models aiming to measure the impact of CSR applications on company's overall performance. 
As one of the first academic studies on the CSR reports of the Turkish companies, Robertson (2009) compared social responsibility applications and reporting in Turkey, Singapore and Ethiopia and proposed that there is need for redefining CSR for developing countries by taking cultural, social, political, and economic factors into consideration, rather than standardizing CSR activities in all over the world. Ertuna and Tukel (2009) conducted a content and impact analysis of CSR disclosures of Turkish companies in ISE50 index and found that social responsibility activities are mainly realized as a part of traditional philanthropic activities of family owned companies as well as profit-oriented activities. Later, Nuhoglu and Wan (2012) studied corporate social responsibility disclosures of 271 manufacturing companies in Turkey and China in the year 2009 concluding that though both countries present rather low levels of CSR practices, Chinese companies' scores are lower than Turkish companies' scores, especially in the domain of economy and society.

With the increasing number of Turkish companies involving in CSR reporting, academic studies on the content analysis of the reports have also increased. Çetinkaya et al. (2015) reviewed corporate social responsibility reports of 48 companies from the Borsa Istanbul (BIST) Corporate Governance Index in terms of Caroll's CSR Pyramid and concluded that philanthropic responsibility was found to have priority for community stakeholder groups, economic responsibility is important for suppliers and legal responsibility is important for environment stakeholder groups. Demir et al. (2016) reviewed 176 sustainability reports in Turkey between 2005-2014 in GRI database and found that large amount of companies in Turkey prefer to invest in educational projects as part of social responsibility activities. Duman et al. (2016) compared CSR practices in construction industry in UK and Turkey. As one of the recent studies on CSR, Öztürk and Marşap (2018) made a comparative content analysis of corporate social responsibility reporting in Telco industry in US, UK and Turkey and concluded that telco industry in general focuses more on the community issues such as education, healthcare, protecting rights of children and women and relatively less on the environmental issues.

As parallel to content analysis of CSR reports, some academic studies started to evaluate the impact of the CSR reports on the performances of the companies in Turkey. Aras et al. (2011) analyzed interaction between value added intellectual capital (VAIC) and CSR on a sample of manufacturing companies listed on the Istanbul Stock Exchange (ISE) during the period 2007-2008 and they could not find any significant relationship between CSR and VAIC during the period analyzed. Arsoy et al. (2012) investigated relationship between CSR and company financial performance of 28 companies in Turkey listed in Istanbul Stock Exchange Corporate Governance Index and found that companies having good financial performance also have better social responsibility scores. Ozcelik et al. (2014) studied the impact of financial performance, firm size, firm risk, type of ownership on CSR of selected companies in ISE and found a significant relationship between firm size and 
corporate social responsibility. Akdoğan et al. (2017) reviewed corporate social responsibility reporting in the Turkish banking industry between the years 2012-2014 to measure the relationship between CSR and corporate governance. They found that corporate governance level has significant impact on the level of CSR reporting in Turkish banking sector. Değer and Aydogan (2018) developed an econometric model measuring the impact of CSR on company financial performance and argue that companies with higher CSR score have higher ROA and Tobin's Q performance. It can be argued that the results of the recent academic studies generally support the idea that CSR reports impacts positively company performances.

As can be seen from the review of the literature in Turkey, the literature on CSR is newly developing area in Turkey and needs to be contributed with the new academic studies in the field as the number of Turkish companies publishing CSR reports has been increasing with the growing interest in CSR reporting among Turkish companies. This paper aims to contribute academic literature in Turkey by making a recent and thorough review of CSR reports of Turkish companies in terms of their contents as well as making a comparison with its neighboring countries in order to see the intra-regional variations in CSR reporting that is lacking in the current literature. Russia and Greece are selected as the peer companies for the regional analysis since both countries share more similarities in the region in terms of economic development level and social structures with Turkey as compared to the other countries in the adjacent region.

\section{CSR and sustainable accounting application in Turkey}

\subsection{Important milestones in the development of sustainability and CSR in Turkey}

The concepts of sustainability and corporate social responsibility first came to focus of Turkish companies and academics in the late 1900's and early 2000's. Turkish government was in the leading role in bringing sustainability issues into the attention of public awareness and business environment through signing of various international treaties of the United Nations. Turkey signed UN Convention on Biodiversity in 1991, UN Convention to Combat Desertification in 1994 and UN Framework Convention on Climate Change in 2004. Turkey also signed Kyoto protocol in 2009 which aims to strengthen enforcement of UN Framework Convention on Climate Change that commits state parties to reduce greenhouse gas emissions to fight against global warming.

The period between 2003- 2007 was an intense period in which national actions and policies being implemented. In 2004, Turkish National Sustainable Development Commission was gathered. National Action Plan on sustainability was prepared in 
2005 in accordance with the terms of international treaties Turkey has signed. In this period Turkey has also prepared the first EU Integrated Environmental Adaption Strategy and started to become an active member of European Environment Agency.

In order to foster sustainable development and increase awareness in the business about sustainable development and corporate social responsibility, the Business Council for Sustainable Development Turkey (BCSD Turkey) was founded in 2004 under the leadership of 13 private sector entities. BCSD Turkey is the local network and partner of the World Business Council for Sustainable Development (WBCSD) in Turkey, and it is in a strong cooperation with its parent organization. The Council shares knowledge on sustainability with its members and stakeholders through the activities of its working groups.

Currently BCSD Turkey has 58 member companies from 19 different sectors composing one third of Turkey's Gross National Product (GNP). In line with UN sustainability goals, BCSD Turkey has continuing its activities in four activity areas as 1- Transition to Low Carbon Economy and Efficiency 2- Sustainable Agriculture and Access to Food 3- Sustainable Industry and Circular Economy 4- Social Inclusion

One of the most prominent steps in Turkey in the field of sustainability in general and corporate social responsibility in particular is the introduction of the Sustainability Index in Istanbul Stock Exchange (ISE) ${ }^{i}$. BIST Sustainability Index was first initiated in 4.11.2014 (XUSRD) aiming to evaluate use of economic, social, environmental factors and corporate governance principles by the companies and to make investors aware of these companies. In 2014, XUSRD Index was covering 30 companies in ISE-30 Index in which for each company daily price and return calculations are launched. Starting value of the XUSRD Index was accepted as closing price of ISE-30 Index as of 3.11.2014 that was 98.020,09. Maximum percentage is restricted with $15 \%$ for one share. Staring from 2018, the coverage of XUSRD Index was extended to 50 companies in ISE-50 Index. Also, companies in ISE-100 Index are voluntarily allowed be included in XUSRD Index. NovemberOctober period is defined as the yearly index period ${ }^{\mathrm{ii}}$.

The companies in the XUSRD Index are evaluated in terms of international sustainability criteria and their adherence to environmental, corporate social responsibility and corporate governance principles by Ethical Investment Research Services Limited (EIRIS). EIRIS use only publicly available information in its evaluations.

The evaluation of EIRIS is made in three steps. In the first step, as of mid-year (June 30th), EIRIS prepares a company profile for each company quoted in Istanbul Stock Exchange Index (ISE) based on publicly available information ${ }^{\mathrm{iii}}$ on policies and activities of these companies with regards to environment, biodiversity, climate change, structure of board of directors, human rights, fight against bribery. Then, 
EIRIS sends prepared profiles to the companies for their evaluations. In the second step companies review their profiles and send back to EIRIS with their recommendations and updates. In the last step EIRIS finalize company profiles considering also recommendations and updates of the companies. In this step, EIRIS also defines list of companies to be included in sustainability index according to index selection criteria. In order to be included in the index, rates of companies should exceed certain thresholds in the predefined selection criteria.

The latest price data are used for the index calculation. The below-given formula is used to calculate index.

$E t=\frac{\sum_{\mathrm{i}=1}^{\mathrm{n}}\left(\frac{\mathrm{Fit}}{D t}\right) * N i t * H i t * \text { Kit }}{\mathrm{Bt}}$

Here,

$\mathrm{Et}=$ Index value at time $\mathrm{t}$

$\mathrm{N}=$ Number of shares included in the index

Fit $=$ Price of share $\mathrm{i}$ in time $\mathrm{t}$

Nit $=$ Total number of shares of $i$ in time $t$

Hit= Ratio of Shares in actual circulation to the Total number of shares for share $\mathrm{i}$ in time $\mathrm{t}$

$\mathrm{Kit}=$ Coefficient of share $\mathrm{I}$ in time $\mathrm{t}$

$\mathrm{Dt}=$ Value of exchange rate of index in time $\mathrm{t}$

$\mathrm{Bt}=$ Denominator of index in time $\mathrm{t}$

\subsection{Implementation of sustainability reporting and CSR in Practice}

Emergence of the concept of sustainability and corporate social responsibility in Turkey in late 1990's and early 2000's coincide with increasing integration of Turkish companies with international economy. Turkish companies started to initiate environmental protection, promotion of social welfare and justice and educational projects to gain competitive advantage in global arena and to increase their brand value in the eyes of national and international customers. Turkish government also promoted corporate social responsibility and sustainability projects of the companies as they see it as an indispensable part of sustainable economic development of the country.

Although there have been considerable developments in CSR and sustainability reporting in Turkey in the last decade, the total number of companies preparing sustainability reports still remains low. According to results of a comprehensive research made by SUSCR, which covers the top 501 companies in Turkish economy in 13 different sectors, the ratio of non-financial reporting among 501 companies is $25.5 \% .38 \%$ of these companies report non-financial information within their annual reports, while $43 \%$ of these companies prepare separate sustainability reports or other non-financial reports. In terms of sectoral breakdown, technologycommunication, healthcare-FMCG and energy are the top three sectors in preparing 
non-financial reports. (EU Sustainability Reporting National Review Report for Turkey, 2016). The low percentage of sustainability reporting among Turkish companies can be attributed to the fact that according to Turkish regulations, companies are not obliged to report their sustainability activities and CSR projects and to prepare sustainability reports on a regular base. Those companies having international connections, adhering to corporate governance principles and giving importance to brand value voluntarily prepare sustainability reports and involve in CSR projects.

Turkish companies have started to prepare sustainability reports from 2004. The first sustainability report that we came across in GRI database was prepared by Aksa Akrilik for the year 2004. Aksa Akrilik is a textile and apparel producing company in Turkey and the report is named as "2004 Sustainable Development Report". Aksa Akrilik was the first and only company that prepared sustainability report in 2004 and the number of companies preparing sustainability report increase two in 2005. The year 2011 was the turning year for sustainability reporting in that after 2011 the total number of companies preparing sustainability reports in GRI database jumped 38 which also coincides with the growing awareness in the Turkish society and business environment of the importance of social responsibility projects and activities.

Until 2010, companies had used various names to report their CSR activities like sustainability report, sustainable development report, corporate social responsibility report, corporate responsibility report, citizenship report, UN Global Impact Progress Report or as an appendix to their annual report. Starting from 2010, the naming of the reports has standardized and currently most companies name their reports as "Sustainability Report".

\section{Research methodology}

In order to evaluate the practical application of sustainability reporting and corporate social responsibility in Turkey, we conducted research in Global Reporting Initiative (GRI) database for sustainability reports for Turkish companies. It is seen that 36 Turkish companies published their sustainability reports in GRI Database in 2016. For our research, we selected 15 companies among 36 for our analysis, each representing different sectors.

Table 1. List of Selected Companies in GRI Database Published Sustainability Report in 2016 ${ }^{\mathrm{iv}}$

\begin{tabular}{cllcc}
\hline \# No & Company Name & \multicolumn{1}{c}{ Sector } & Listed / Unlisted & Included in XUSRD Index \\
\hline 1 & Abdi İbrahim & Healthcare & Unlisted & Not Included \\
2 & Akbank & Financial Services & Listed & Included in XUSRD \\
3 & Akenerji & Energy & Listed & Included in XUSRD \\
4 & Aksa Akrilik & Textile and Apparel & Listed & Included in XUSRD \\
\hline
\end{tabular}




\begin{tabular}{cllcc}
\hline \# No & Company Name & \multicolumn{1}{c}{ Sector } & Listed / Unlisted & Included in XUSRD Index \\
\hline 5 & Aselsan & Technology and Defense & Listed & Included in XUSRD \\
6 & Boyner & Retail & Listed & Not Included \\
7 & Çimsa & Construction & Listed & Included in XUSRD \\
8 & Dogus Oto & Automotive & Listed & Included in XUSRD \\
9 & Erdemir & Metal Production & Unlisted & Included in XUSRD \\
10 & ISS Turkey & Commercial Services & Unlisted & Not Included \\
11 & Polisan Holding & Chemicals & Listed & Included in XUSRD \\
12 & Sisecam & Consumer Products & Listed & Included in XUSRD \\
13 & Turkcell & Telecommunication & Listed & Included in XUSRD \\
14 & Turkish Airlines & Aviation & Listed & Included in XUSRD \\
15 & Zorlu Holding & Conglomerates & Listed & Included in XUSRD \\
\hline
\end{tabular}

Source: GRI Database (www.globalreporting.org)

It is seen from the sectoral analysis of the reports in GRI database, Financial Services, Conglomerates (Holdings), Textiles and Apparel and Health Care Products are more active sectors in sustainability reporting, although companies from 15 sectors are represented in GRI.

The analysis of CSR literature shows that nature and type of CSR initiatives are one of the important concerns among scholars. In line with the relevant literature, in order to see nature and type of CSR initiatives in Turkey and in the neighboring region, we analyze the sustainability reports according to type of CSR activities and the main CSR activity areas. We also want to analyze the main motivations of the companies in undertaking CSR activities and how widespread CSR reporting framework is among companies which are missing in the literature. Three criteria are defined to analyze sustainability reports of the companies, as we explain next.

\subsection{Content analysis of sustainability reports in Turkey}

We analyze the sustainability reports of selected 15 Turkish companies gathered from GRI database according to 1- focus areas in CSR activities 2- overall aim of the company expected from CSR activities 3- types of sustainability reporting frameworks (See Appendix 2).

Priority areas of Turkish companies in CSR projects shows Turkey's strive for achieving economic development more than cultural and social development. Expectations of companies from realizing CSR projects also show that companies consider CSR projects as a tool to increase their competitive abilities locally and internationally, to increase net profit level and their overall company value. Companies expect direct economic and financial results from CSR activities rather than realizing them as a result of a more elevated understanding of being a responsible company towards its society and environment. 
Among all CSR activities, supporting education is by far the most prominent area in CSR projects for Turkish companies, reflecting the idea in Turkish society of considering education as a main vehicle for realizing economic development. Regardless of its sector, almost all companies undertake different CSR projects to support various educational and training activities especially towards children and young people through organizing training facilities and fund-raising activities. Family owned large conglomerates realize their philanthropic activities for education through their family owned foundations.

Projects to support status of women and disabled people in society are another focus of activity in CSR projects. It includes women empowerment projects, supporting women's entrepreneurship, easy access to financial resources for women, supporting disabled people financially and through equipment providence.

Environmental projects have relatively less weight in total CSR activities of the companies as compared to other activity areas although almost all companies undertake some level of environmental projects like waste management, recycling and clean energy. Supporting art, cultural and sport activities in society is the least preferred CSR activity area for Turkish companies.

In terms of reporting frameworks, Turkish companies prepare sustainability reports in conformity with GRI G4 and UNGC COP reporting. There is less preference for other reporting frameworks like integrated reporting and CDP reporting.

\subsection{CSR and sustainable accounting in the neighboring regions}

\section{Practical application of CSR and sustainability reporting in Russia}

The first sustainability reports in Russian Federation published in GRI database was prepared by North-West Timber Company in 2003 . The report was firstly prepared as "2003 Environmental Report". Following the first report, Lukoil and Norilsk Nikel started to prepare sustainability reports in 2004 and 2005. Recently, there are 230 listed companies in Russian Exchange MOEX and the number of sustainability reports in GRI database published by Russian companies was 80 by the end of 2016 as heavily dominated by energy companies, though most reports are written in Russian that does not allow well satisfactory content analysis of the reports with a limited sample amount, we can still draw conclusions from our analysis of the reports and see the main activity areas and drivers of CSR initiatives in Russia.

Analysis of the English written sustainability reports of Russian companies in GRI database as of 2016 reflected social and economic priority areas in Russian society. Although there were nuances in CSR activities among companies according to sectoral differences, we see that CSR activities accumulated in certain priority areas in Russian Federation. 
The common priority areas in CSR activities in Russia can be classified as

- increasing workplace conditions, safety and employee rights,

- implementing corporate governance and anti-corruption policies,

- reducing water consumption, carbon emission and recycling projects,

- supporting children and especially disabled children in society,

- promoting family and general health in society and

- sponsoring sports and cultural activities.

In general, it is seen that energy, water consumption, environmental projects and workplace safety are considered by Russian companies important CSR activity areas. Russian companies also give importance to implementing corporate governance principles and anti-corruption measures. Sponsoring sports and cultural activities like cinema and theatre also constitute important area for CSR. On the other hand, we cannot see any CSR project for promoting education and women empowerment in Russia. Russian companies prefer to invest in projects for general empowerment of society and family, without making any gender differentiation.

\section{Practical application of CSR and sustainability reporting in Greece}

The sustainability reports in GRI database were published by Greek companies starting from 2002. Vodafone Greece and Motor Oil Hellas were the first sustainability report publishing companies in 2002. As of 2016 the number of sustainability reports publishing company in GRI database is 53 and the number of listed companies in Greek Exchange is 196, though, as Russian Federation, absence of the English written sustainability reports representing all sectors in Greece limits selection of our sample.

Review of the English written sustainability reports published in GRI database shows that focus area for Greek companies in CSR activities revolve around helping children and children's foundations, promoting employee development and workplace conditions and protecting environment with recycling projects, reducing energy, water consumption and carbon emission level. There are also CSR projects to protect cultural sites and support historical events. Issues of education, gender equality and equality in society in general, promoting family and health in society do not get much attention among Greek companies as a CSR activity focus. This can be partly attributed to the fact that Greece has comparatively high level of social development as a European Union member country, although she is geographically adjacent to Turkey and Russian Federation.

\section{Comparative analysis and findings}

\subsection{Coverage of the reporting}

The table below shows the number of companies publishing sustainability reports in Turkey, Russian Federation and Greece by $2016^{\mathrm{v}}$. 
Table 2. Country breakdown of number of listed companies and companies in GRI Database

\begin{tabular}{lccr}
\hline & Turkey & Russian Federation & Greece \\
\hline $\begin{array}{l}\text { Number of Listed } \\
\begin{array}{l}\text { Companies } \\
\text { Number of Companies }\end{array}\end{array}$ & 374 & 230 & 196 \\
$\begin{array}{l}\text { Publishing Sustainability } \\
\text { Reports in GRI in 2016 * }\end{array}$ & 40 & 80 & 53 \\
$\begin{array}{l}\text { Coverage Rate (\%) } \\
\text { Source: GRI Database, Global Economy.com } \\
* \text { All types of reports in GRI database are included. }\end{array}$ & 34.78 & 27.04 \\
\hline
\end{tabular}

It is seen that a relatively high number of companies prepares sustainability reports in Russia and Greece as compared to Turkey. Nearly 35\% of all listed companies in Russian Federation and $27 \%$ of all listed Greek companies are preparing sustainability reports for the year 2016 . While the ratio of sustainability report preparing companies among all listed companies in Turkey is around $11 \%$ although the number of listed companies in Turkey are relatively higher than Russia and Greece. The existence of low coverage among Turkish companies shows that sustainability reporting is a newly developing area in Turkey and there is still big room for development in the field of sustainability reporting.

\subsection{Main CSR activity areas}

Content analysis of the sustainability reports between Turkey, Russia and Greece highlights existence of differences between these countries in terms of CSR activity areas. CSR activity areas in Turkey underline Turkey's strive for achieving social and economic development as a newly developing country. The CSR focus areas in Turkey reflect existence of an understanding in Turkish society that prioritizes economic development over social development. It is believed that in order to achieve economic development, education and innovation should be supported. For this reason, we see more focus on education and innovation projects issues among Turkish companies and less focus on environmental although all of them pursue some level of environmental projects like recycling, waste management. Turkish companies consider CSR projects as a means to support Turkey's economic and social growth and development. As stated in most sustainability reports of Turkish companies, Akbank Chairman states that

"In addition to maintaining strong support for Turkey's economic growth, Akbank also contributed to the country's social development through its focus on education, culture, art, entrepreneurship, and volunteering as prioritized social investment areas." (Akbank Sustainability Report, 2016) 
The biggest activity area for Turkish companies is characterized by investing in educational facilities and supporting women and disabled people in society. Education is considered by almost all Turkish companies analyzed as indispensable element of corporate social responsibility. Mainly the conglomerates and their affiliated companies like Zorlu Holding, Akbank, Şişecam, Turkcell take the leading role in educational support activities. Zorlu Holding states their motto as "constructing roofs for young people" in giving support to education of young people (Zorlu Holding Sustainability Report, 2016). The other focused area for CSR is supporting innovation especially among younger generation.

Many companies undertake innovation support activities similar to "The CaseCampus Program" of Akbank which is a joint venture with Endeavor Turkey attended by young people from all parts of Turkey dreaming of starting their own business (Akbank Sustainability Report, 2016).

Apart from education and innovation, Turkish companies initiate various CSR activities to support women in society and women empowerment projects. Stronger Young Women project of retail group Boyner aims to promote the continuing education of young female high school graduates, age 18-24, who grew up in orphanages and are exposed to social and economic discrimination. The project teaches them how to be ready for the business market by developing their skills and personal development (Boyner Sustainability Report, 2016). Similar To Boyner, Dogus Oto is the other company promoting the women empowering initiatives as stated in their reports:

"we are striving to create exemplary opportunities for women's employment in the business world by updating our human resources policy, increasing women's participation in the business world, becoming a company preferred by women employees, and bringing different perspectives to our organization.” (Doğuş Oto Sustainability Report, 2016)

CSR projects aiming to support family and elderly people in society are least focused areas in Turkey since family and patriarchal ties are still very strong in Turkey as a traditional and family-oriented society. Traditional structure of Turkish society also defines intensity of CSR activities. Even though CSR is a newly developed concept in Turkey which is imported from developed countries of the west, the number and magnitude of CSR projects in Turkish companies are high as compared to the number and magnitude of CSR projects in Russia and Greece. It can be said that existence of a traditional philanthropic culture in Turkish society intensifies CSR activity in Turkey.

CSR activities in Russia concentrate on energy saving and environmental protection projects which can be attributed to dominance of Russian economy by energy sector. As one of the biggest employer company in Russian Federation, Lukoil implements a big scale environmental and industrial safety program across Russian Federation. 
The other important CSR activity areas in Russia are supporting family and society in general. Due to structure of Russian society, Russian companies prioritize CSR projects to support family in society and children's foundations. Aeroflot initiates a support program for WW2 veterans which aims to give material aid to WW2 veterans in Russia. The same company also charity programs for children and disabled people in society (Aeroflot Sustainability Report, 2016). The Russian companies also put emphasis on implementing anti-corruption and corporate governance principles together with increasing workplace conditions and safety measures. Supporting cultural and sport activities are another focus area for Russian companies. Education and women are not considered as main CSR activity areas in Russia.

Environmental projects constitute focus area for CSR activities in Greece. Unlike Russian companies, Greek companies invest in environmental projects mainly because of requirements of European Union regulations. Social aspect of CSR in Greece is limited with promoting employee development and workplace conditions. There are also CSR projects for supporting and sponsoring cultural activities, sports in society and helping children's foundations. Similar to Russia, education and women empowerment does not considered as CSR activity area by Greek companies also.

The analysis of CSR activity areas indicates the variations in socio-economic structure of the selected countries. Turkey's social structure as a patriarchal and predominantly Muslim populated society differentiates her CSR activity areas from the neighboring countries of Greece and Russia. While environmental projects and the projects aiming to promote place of family and elderly people in society are the main CSR activity areas in Greece and Russia, Turkish companies place less emphasis on social CSR activities like promoting family, protecting elderly people in society, supporting cultural events, sports and sponsoring activities.

\section{Conclusion}

As Argodona and von Weltzien Hoivik (2009) state, corporate social responsibility represents a complex notion for corporate actors and there is no such thing as a onesize-fits-all CSR solution. The analysis of CSR activities in Turkey in comparison with the CSR activities in Russian Federation and Greece shows that there is no unique understanding of CSR among these countries. Socio-economic development levels and social structures of the countries shape the understanding of CSR. In their comprehensive studies that compares selected European clusters composed of 178 corporations from various European countries, Maon et al. (2017) puts that:

"the notion of CSR as a contextualized concept, shaped by socio-political drivers, and contributes by bridging macro-level, socio-political facets of CSR with its meso-level, organizational implications." 
CSR priority areas and activities in Turkey highlight socio-economic development level and social-religious structure of Turkish society which is also reflected in practical application of CSR projects implemented by Turkish companies.

It is seen that Turkey's strive for achieving economic development shapes whole understanding of CSR in Turkey. Turkish companies prefer to invest in CSR projects that will directly contribute to the economic development of the country. For this reason, supporting education of children, younger people and innovation are prioritized as CSR activity areas, while environmental projects and cultural activities remain as less focused areas. In addition to achieving economic development, projects which aims to promote place of women in society are the other prominent CSR activity area in Turkey due to social and religious structure of Turkish society. In this sense, CSR activity and priority areas can be seen as an indicator for social structure and socio-economic development level of any country. Ertuna and Tukel (2009) classify Turkey "a country in between traditional and global" in terms of CSR activities and sustainability.

Country specific socio-economic structures of Russian Federation and Greece shape understanding of CSR in a different way. Environmental protection, enhancing workplace conditions and safety, implementing corporate governance principles, supporting family in society and sponsoring sport and cultural activities are seen main CSR priority areas in Russia Federation and Greece leaving education, innovation and women empowerment projects in an inferior place.

In this study, we conducted our research on CSR applications and practices based on sustainability reports in GRI database leaving the actual practices and behaviors of the companies on CSR out of the scope of this study. There should be more studies in the future focusing on actual practices and strategies of the companies that is reflecting the real CSR behaviors of the companies in Turkey and in the neighboring region.

\section{References}

Al-Abdin, A. Roy, Nicholson, D. J. (2018) "Researching corporate social responsibility in the Middle East: the current state and future directions", Corporate Social Responsibility and Environmental Management, 25, pp: $47-65$

Akdoğan, N., (2017) "Reporting and auditing of financial and non-financial information in the frame of corporate sustainability", 14th International Conference on Accounting, Tirana, Albania, 2017

Akdoğan, N. Gulhan, O. Aktaş, M. (2017) "The relationship between corporate social responsibility reporting and corporate governance: evidence from Turkish banking sector", Journal of Modern Accounting and Auditing, May 2017, Vol 13, No 5, pp. 181-195 
Albu, C. N. Balsari, Ç. Krasodomska, J. (2016) "Introduction to the special issue on corporate social reporting in Central and Eastern Europe", Accounting and Management Information Systems Vol. 15, No. 2, pp. 193-205

Albareda, L., Lozano, J., \& Ysa, T. (2007) "Public policies on corporate social responsibility: the role of governments in Europe", Journal of Business Ethics, vol. 74(4): 391-407

Aras, G. Aybars, A. \& Kutlu, O. (2011) "The interaction between corporate social responsibility and value added intellectual capital: empirical evidence from Turkey”, Social Responsibility Journal, vol. 7(4): 622-637

Argandona, A. \& von Weltzien Hoivik, H. (2009) "Corporate social responsibility: one size does not fit all: collecting evidence from Europe", Journal of Business Ethics, vol. 89(3): 221-234

Arsoy, P. A. Arabacı, Ö. Çiftçioğlu, A. (2012) "Corporate social responsibility and financial performance relationship: the case of Turkey", Muhasebe ve Finansman Dergisi, January 2012, pp: 159-176

Aupperle, K., Hatfield, J.D. \& Carroll, A.B. (1983) "Instrument development and application in corporate social responsibility", Academy of Management Proceedings, pp. 369-373

Barnard, C.I. (1968) "Comments on the job of the executive", Harward Business Review, pp: 295-308

Beelde, I. \& Tuybens, S. (2015) "Enhancing the credibility of reporting on corporate social responsibility in Europe", Business Strategy and the Environment, no. 24: $190-216$

Borsa İstanbul. (2017) "BİST sürdürülebilirlik endeksi temel kuralları" (www.borsaistanbul.com)

Borsa İstanbul. (2018) "Şirketler için sürdürülebilirlik rehberi" (www.borsaistanbul.com)

Bowen, H.R. (1953) Social responsibilities of the businessman, NewYork: Harper and Brothers

Carroll, A.B. (1979) "A three-dimensional conceptual model of corporate performance", Academy of Management Review, vol. 4(4): 497-505

Carroll, A.B. (1991) "The pyramid of corporate social responsibility: toward the moral management of organizational stakeholders", Business Horizons, vol. 34: 39-48

Chiu, I.H.Y. (2010) "Standardization in corporate social responsibility reporting and a universalist concept of csr? - a path paved with good intentions", 5th Global Responsibility Conference in Lisbon, Sept. 23-25

Çetinkaya, M., Ağca, V. \& Özutku, H. (2015) "Priorities for corporate social responsibility reporting: evidence from listed Turkish Companies in Istanbul Stock Exchange", Journal of Economic and Social Studies, vol. 5: 57-77

Deger, A. \& Aydogan, E. (2018) "Kurumsal sosyal sorumluluğun firma performansına etkisi: Türkiye örneği”, Uludă̆ Üniversitesi Fen-Edebiyat Fakültesi Sosyal Bilimler Dergisi, vol. 19: 185-214 
Demira, G., Cagle, M. M. \& Dalkılıç, F. (2016) "Corporate social responsibility and regulatory initiatives in Turkey: Good implementation examples", Accounting and Management Information Systems, vol. 15(2): 372-400

Duman, D. U., Giritli, H. \& McDermott, P. (2016) "Corporate social responsibility in construction industry: A comparative study between UK and Turkey", Environment Project and Asset Management, vol. 6(2): 218-231

EIRIS (2015) "BIST Sustainable index research methodology", Empowering Responsible Investment, December 2015

Ertuna, B. \& Tükel, A. (2009) "Türkiye'de kss uygulamaları: geleneksel ve küresel arasında", Yönetim Araştırmaları Dergisi 145 2009, cilt 9, sayı 2, pp. $145-172$

European Union Project (2016) Turkey Sustainability Reporting National Review Report

Gambetta, N., Benau, M. \& Grima, A. (2017) Corporate social responsibility and bank risk profile: evidence from Europe, Springer, pp: 517-542

Global Reporting Inıtiative. Reporting Database (www.globalreporting.org)

Hing, N. (2001) "Changing the odds: A study of corporate social principles and practices in addressing prohlem gambling", Journal of Business Ethics, vol. 33: $115-144$

Jackson, G., Apostolakou, A. (2010) "Corporate social responsibility in Western Europe: an institutional mirror or substitute?", Journal of Business Ethics, vol. 94(3): 371-394

Jain, A., Leka, S. \& Zwetsloot, G. (2011) "Corporate social responsibility and psychosocial risk management in Europe", Journal of Business Ethics, no. 101: 619-633

Kılıç, B.İ. (2018) "Entegre raporlama ve Türkiye'deki gelişmeler: entegre rapor hazırlayan işletmeler ve bist kurumsal sürdürülebilirlik endeksinde yer alan işletmeler açısından bir inceleme", Muhasebe Bilim Dünyası Dergisi, Mart 2018; 20(1): 28-64

Maon, F. Swaen, V. \& Lindgreen, A. (2017) "One vision, different paths: an investigation of corporate social responsibility initiatives in Europe", Journal of Business Ethics, vol. 143: 405- 422

Nastiti, A.L. Sukoharsono, E. G. \& Nurkholis. (2017) "Carroll's pyramid and the implementation of corporate social responsibility in 'Pt Pupuk Kalimantan Timur'”, International Journal of Research In Commerce \& Management, vol. $8: 10-15$

Nuhoğlu, N. İ. WAN, L. (2012) "Corporate social responsibility disclosure in two rising actors: China And Turkey", MÖDAV, pp. 87-112

Ozturk, C. \& Marsap, B. (2018) "Corporate social responsibility reporting in telecommunication industry: The Case of the US, UK, and Turkey", Muhasebe Finansman Dergisi, April 2018 
Özcelik, F., Özturk, B. \& Gürsakal, S. (2014) "Investigating the relationship between corporate social responsibility and financial performance in Turkey", Atatürk Üniversitesi İktisadi ve İdari Bilimler Dergisi, Cilt: 28, Say1: 3: 189-204

Pekdemir, R. (2013) "Corporate sustainability in developing countries: needs and facts", 10th International Accounting Conference, İstanbul, 2013

Robertson, D. C. (2009) "Corporate social responsibility and different stages of economic development: Singapore, Turkey, and Ethiopia", Journal of Business Ethics, vol. 88: 617-633

Segot, T.L. (2011) "Corporate social responsibility as a bolster for economic performance: evidence From Emerging Markets", Global Business and Organizational Excellence, November/December, pp: 38-54

Schwartz, M. \& Carroll, B.A. (2003) "Corporate social responsibility: a threedomain approach", Business Ethics Quarterly, vol. 13: 503-530

The global economy (https://www.theglobaleconomy.com/France/Listed_ companies/)

Appendix 1. Companies in XUSRD Index in November 2018 - October 2019 Period

\begin{tabular}{|c|c|c|c|c|c|c|c|c|}
\hline 1 & AKENR & AK ENERJI & 18 & GARAN & $\begin{array}{l}\text { GARANTI } \\
\text { BANKASI }\end{array}$ & 35 & TSKB & T.S.K.B. \\
\hline 2 & AKBNK & AKBANK & 19 & GLYHO & $\begin{array}{l}\text { GLOBAL YAT. } \\
\text { HOLDING }\end{array}$ & 36 & TATGD & TAT GIDA \\
\hline 3 & AKSA & AKSA & 20 & ISCTR & IS BANKASI & 37 & TAVHL & $\begin{array}{l}\text { TAV } \\
\text { HAVALIMANLARI }\end{array}$ \\
\hline 4 & AKSEN & $\begin{array}{l}\text { AKSA } \\
\text { ENERJI }\end{array}$ & 21 & KCHOL & $\begin{array}{l}\text { KOC } \\
\text { HOLDING }\end{array}$ & 38 & TKFEN & TEKFEN HOLDING \\
\hline 5 & ANACM & $\begin{array}{l}\text { ANADOLU } \\
\text { CAM }\end{array}$ & 22 & KORDS & $\begin{array}{l}\text { KORDSA } \\
\text { TEKNIK } \\
\text { TEKSTIL }\end{array}$ & 39 & TOASO & TOFAS OTO. FAB. \\
\hline 6 & AEFES & $\begin{array}{l}\text { ANADOLU } \\
\text { EFES }\end{array}$ & 23 & LOGO & $\begin{array}{l}\text { LOGO } \\
\text { YAZILIM }\end{array}$ & 40 & TUPRS & TUPRAS \\
\hline 7 & ANELE & $\begin{array}{l}\text { ANEL } \\
\text { ELEKTRIK }\end{array}$ & 24 & MGROS & $\begin{array}{l}\text { MIGROS } \\
\text { TICARET }\end{array}$ & 41 & THYAO & $\begin{array}{l}\text { TURK HAVA } \\
\text { YOLLARI }\end{array}$ \\
\hline 8 & ARCLK & ARCELIK & 25 & NETAS & $\begin{array}{l}\text { NETAS } \\
\text { TELEKOM. }\end{array}$ & 42 & TTKOM & TURK TELEKOM \\
\hline 9 & ASELS & ASELSAN & 26 & OTKAR & OTOKAR & 43 & TTRAK & TURK TRAKTOR \\
\hline 10 & AYGAZ & AYGAZ & 27 & PGSUS & PEGASUS & 44 & TCELL & TURKCELL \\
\hline 11 & BRISA & BRISA & 28 & PETKM & PETKIM & 45 & ULKER & ULKER BISKUVI \\
\hline 12 & CIMSA & CIMSA & 29 & POLHO & $\begin{array}{l}\text { POLISAN } \\
\text { HOLDING }\end{array}$ & 46 & VAKBN & $\begin{array}{l}\text { VAKIFLAR } \\
\text { BANKASI }\end{array}$ \\
\hline 13 & CCOLA & $\begin{array}{l}\text { COCA } \\
\text { COLA } \\
\text { ICECEK }\end{array}$ & 30 & SAHOL & $\begin{array}{l}\text { SABANCI } \\
\text { HOLDING }\end{array}$ & 47 & VESTL & VESTEL \\
\hline 14 & DOHOL & $\begin{array}{l}\text { DOGAN } \\
\text { HOLDING }\end{array}$ & 31 & SKBNK & SEKERBANK & 48 & VESBE & $\begin{array}{l}\text { VESTEL BEYAZ } \\
\text { ESYA }\end{array}$ \\
\hline 15 & DOAS & $\begin{array}{l}\text { DOGUS } \\
\text { OTOMOTIV }\end{array}$ & 32 & SISE & SISE CAM & 49 & YKBNK & $\begin{array}{l}\text { YAPI VE KREDI } \\
\text { BANK. }\end{array}$ \\
\hline
\end{tabular}




\begin{tabular}{|c|l|l|c|l|l|l|l|l|}
\hline 16 & EREGL & $\begin{array}{l}\text { EREGLI } \\
\text { DEMIR } \\
\text { CELIK }\end{array}$ & 33 & SODA & $\begin{array}{l}\text { SODA } \\
\text { SANAYII }\end{array}$ & 50 & ZOREN & ZORLU ENERJI \\
\hline 17 & FROTO & $\begin{array}{l}\text { FORD } \\
\text { OTOSAN }\end{array}$ & 34 & HALKB & $\begin{array}{l}\text { T. HALK } \\
\text { BANKASI }\end{array}$ & & \\
\hline
\end{tabular}

Source: Istanbul Stock Exchange (www.borsaistanbul.com)

\section{Appendix 2. Coding}

1- Abdi İbrahim Medicine Ongoing CSR Projects and Sustainability Activity Areas

Strategic Goals and Aims expected from CSR Activities

Reporting Frameworks

2-Akbank

Financial Services

Ongoing CSR Projects and Sustainability Activity Areas

Strategic Goals and Aims expected from CSR Activities

\section{Sector: Healthcare Products}

- Undertaking renovation project for a historical hospital

- Various activities to increase social awareness on healthcare

- Charity activities and donations for children

- Undertaking waste management and recycling projects for environment

- Projects to improve workforce satisfaction and workplace conditions for employees

- Promoting brand reputation and overall value of company

- $\quad$ GRI G4 Reporting

- UNGC Communication on Progress (COP) Reporting

- Women Empowerment Principles (WEP)

Sector:

- Achieve long-term sustainable return on equity of min.15-17\% and create high value for all our stakeholders

- To increase customer experience and satisfaction 
Reporting Frameworks
- $\quad$ GRI G4 Reporting

- UNGC Communication on Progress (COP) Reporting

- $\quad$ Carbon Disclosure Project (CDP) Reporting

\section{3- Akenerji} Ongoing CSR Projects and Sustainability Activity Areas

Strategic Goals and Aims expected from CSR Activities

Reporting Frameworks

Sector: Energy

- Involving in various environmental projects like water management, waste management, greenhouse gas monitoring, energy consumption management, CDP climate change management, tree planting activities

- Investing in clean energy projects

- Promoting occupational health and safety and employee trainings

- Contributing company's overall success in Turkey

- Carbon Disclosure Project (CDP) Reporting: CDP Climate Change and Water Program Report (first energy company in Turkey making CDP reporting)

- UNGC Communication on Progress Report

- $\quad$ GRI G4 Reporting

- Environmental Social Progress Report (internal)

Sector: Textile and Apparel Production (Acrylic fiber producer)

Ongoing CSR Projects and Sustainability Activity Areas

Strategic Goals and Aims expected from CSR Activities

Reporting Frameworks
- Supporting clear energy and green workplace projects

- Increase workplace conditions for workers

- Giving art and music trainings for elementary school students

- To maintain market leadership position and directing the sector

- $\quad$ To create value for stakeholders

- $\quad$ GRI G4 Reporting

- UNGC Communication on Progress (COP) Reporting 
5-Aselsan

Sector: Technology and Defense

Ongoing CSR Projects and

Sustainability Activity Areas

Strategic Goals and Aims expected from CSR Activities

Reporting Frameworks
- To support employee development with various activities and training opportunities

- $\quad$ Projects to decrease carbon disclosure level and waste management

- Fulfilling its commitments to its stakeholders and its customers

- Increasing customer and market diversity

- Generating high value in the long term

- Increasing profit

- $\quad$ GRI G4 Reporting

\section{6-Boyner}

Ongoing CSR Projects and

Sustainability Activity Areas

Strategic Goals and Aims expected from CSR Activities

Reporting Frameworks

\section{Sector: Textile Retail Group}

- Follow workplace improvement and employee development programs

- To support clean energy, green workplace, waste management and carbon emission projects

- Supply chain sustainability project

- Projects for empowering women in society

- Financial and material donations and philanthropic activities for children's education and animals

- To increase customer satisfaction

- $\quad$ GRI G4 Reporting

- UNGC Communication on Progress (COP) Reporting

\section{7-Çimsa}

Ongoing CSR Projects and Sustainability Activity Areas

\section{Sector: Construction (cement)}

- $\quad$ Adopted UN sustainable development goals

- Projects to reduce carbon emission and energy efficiency

- Promoting employee trainings and development

- Supporting actively women empowerment projects

- Supporting education of children and disabled children in society financially 
Strategic Goals and Aims expected from CSR Activities

Reporting Frameworks
- To maintain its competitive production power and continue its growth

- $\quad$ Carbon Disclosure Project (CDP) Reporting

- $\quad$ GRI G4 Reporting
8-Doğuș Oto

Ongoing CSR Projects and

Sustainability Activity Areas

Strategic Goals and Aims expected from CSR Activities

Reporting Frameworks
Sector: Automotive

- $\quad$ Engaging in environmental projects like energy saving, waste management, reducing $\mathrm{CO} 2$ emission level

- Supporting women employment

- Involving in community projects to increase public awareness of traffic safety and regulations

- Consider sustainability as one of the main tools to improve economic performance and shareholders value

- $\quad$ GRI G4 Reporting
9-Erdemir

Ongoing CSR Projects and

Sustainability Activity Areas

Strategic Goals and Aims expected from CSR Activities
Sector: Metal Production

- $\quad$ Aimed to adopt UN Development goals of 6clean water,7-accessible and clean energy,9industry innovation and infrastructure, 12responsible consumption and production,13climate action and 15-terrestrial life.

- Taking active role in civil society and governmental organizations in Turkey on environmental protection

- Launched various CSR projects in three focused areas: occupational health and safety, biodiversity-environment and art

- Engaging in environmental projects for waste management, water management, reduction of emissions, ecolabelling, energy management and biodiversity

- Promoting corporate governance principles end ethical rules in the company

- To contribute its global competitiveness and realizing company's general vision of being best in the world in its product segment 
Ongoing CSR Projects and

Sustainability Activity Areas

Strategic Goals and Aims expected from CSR Activities

Reporting Frameworks
- Following employee satisfaction and development programs via training programs and supporting employees and their children financially in various instances like education, death of a close relatives, health problems, major accidents etc.

- $\quad$ Supporting occupational health and safety

- Reducing energy and water consumption

- Giving scholarships to children of employees

- Becoming the world's greatest service company

- $\quad$ GRI G4 Reporting

\section{1-Polisan Holding}

Ongoing CSR Projects and

Sustainability Activity Areas
Sector: Chemicals

- Adopting 10 principles of UN Global Contact

- Supporting R\&D and innovation to offer ecofriendly products

- Waste and waste-water management activities

- Energy management activities and projects to reduce carbon footprint

- Supporting employee trainings and development

- Involving in socio-cultural projects like building a sport complex, sponsoring cultural events

- To increase customer satisfaction

from CSR Activities

Reporting Frameworks

- $\quad$ GRI G4 Reporting

\section{2-Şişecam}

Ongoing CSR Projects and

Sustainability Activity Areas

\section{Sector: Consumer Products}

- Involving in energy saving and sustainable energy projects 
- Undertaking recycling projects especially for glasses

- $\quad$ Supporting cultural activities in Society and to increase social awareness on glass recycling

- Providing scholarships for children and vocational education

- Engaging in biodiversity projects like tree planting, forest building, supporting ecological structure and wild animals

- $\quad$ Sponsoring sport events and local sport teams

Strategic Goals and Aims expected from CSR Activities

Reporting Frameworks
- Contributing to its global competitiveness and global presence

- Creating value added for financial stability, reducing our environmental impact and generating permanent values for stakeholders.

- $\quad$ GRI G4 Reporting

\section{3-Turkcell

Ongoing CSR Projects and \\ Sustainability Activity Areas}

Strategic Goals and Aims expected from CSR Activities

Reporting Frameworks

\section{Sector: Telecommunication}

- $\quad$ Supporting educational and training of children and undertaking projects to support education of girls

- Undertaking projects to support women and disabled people in society

- Supporting innovation

- Giving support for sport activities and sport teams

- To be a leader in all telecom services in Turkey

- To be a regional leader

- $\quad$ GRI G4 Reporting

- UNGC Communication on Progress (COP) Reporting
14-Turkish Airlines

Ongoing CSR Projects and

Sustainability Activity Areas

\section{Sector: Aviation}

- Promoting various environmental projects to reduce emission level, waste and energy management projects, tree planting and forestry activities

- $\quad$ Supporting employee training and development programs 
- Supporting education of children financially and through material aids

- Involving in global aid and humanitarian activities led by UN and other international organizations

- $\quad$ Supporting cultural events and activities

- Sponsoring sport teams and global sport tournaments

Strategic Goals and Aims expected from CSR Activities

Reporting Frameworks
- To create value for shareholders and to support global competitiveness

- $\quad$ GRI G4 Reporting

\section{5-Zorlu Holding}

Ongoing CSR Projects and

Sustainability Activity Areas

Strategic Goals and Aims expected from CSR Activities

Reporting Frameworks
Sector: Conglomerate

- Charity activities and donations for university students and children through its Zorlu foundation

- $\quad$ Supporting disabled people through various fund-raising projects

- Giving training and educational activities for children on waste management, environment, innovation

- Undertaking waste management, clean energy and recycling projects for environment

- Projects to improve workforce satisfaction and workplace conditions for employees

- Being more competitive in its sector locally and globally

- UNGC Communication on Progress (COP) Reporting

'It is renamed as "Borsa İstanbul" later.

ii The companies included in the latest XUSRD Index period are presented in the appendix 1.

iii Annual reports of the companies, sustainability reports, corporate responsibility reports, web sites of the companies, Carbon Disclosure Project (CDP) Reports, other reports prepared by third parties can be listed as publicly available information used in evaluations. 
iv It is also noteworthy to mention that efforts of the Turkish exchange Borsa Istanbul to support sustainability reporting paved the way in that large amount of companies publishing sustainability reports are listed companies. However, the total number of companies preparing sustainability reports on regular bases is still low considering the fact the total number of listed companies exceeds 300 in Turkey as of our research date

$v$ The same data is also researched for South Korea, Germany and France to gain further insights while making comparisons. The number of listed companies is 2.114 in South Korea, 450 in Germany and 465 in France. The total number of companies publishing sustainability reports in GRI in 2016 is 60 in South Korea, 145 in Germany and 185 in France (coverage ratios are 3\%, 32\% and $40 \%$ for three countries respectively). 